\title{
Maksymilian Chutorański
}

Uniwersytet Szczeciński

\section{Kontrowersje wokół moralnego statusu pedagogicznej codzienności}

\section{Abstract \\ Controversies over the moral status of pedagogical everyday life}

The aim of the text is to draw attention to the controversies over the moral status of pedagogical everyday life. I try to show that the pedagogical thinking and practice is destined to ethical controversy that goes much further than axiological justification for education goals. I draw attention to the three possible view of the relation normativity - everyday teaching/learning. First, it involves strictly to the existence of morality in everyday life. The second relates to the question of what we consider to be subject to moral evaluation and when we refuse such status. Third, in turn, focuses on the question of the possibility of founding morality on the everyday experiences of individuals and groups. In his article, I try to identify the contributions to the pedagogical controversies of each of these areas.

Key words: everyday life, morality, moral education, pedagogical ethics

Słowa kluczowe: codzienność, moralność, wychowanie moralne, etyka pedagogiczna

Jeżeli akceptować twierdzenie, że każdy dyskurs pedagogiczny jest normatywny, a zatem wiąże się z koniecznością rozstrzygania, że powinno być tak, a nie inaczej, oraz że procesy edukacyjne skazane są na codzienność w tym sensie, że właśnie dzieją się w światach codziennych doświadczeń konkretnych osób ${ }^{1}$,

1 Rozpoczynając rozważania, posługuję się ogólnym, a przy tym nieostrym rozumieniem codzienności, które przyjmuję ze świadomością problemów związanych z precyzyjnym ujęciem tego terminu. Jak sądzę, dla prezentowanego wywodu wystarczy, że podkreślimy za Piotrem Sztompką, że „[்̇]ycie codzienne to najbardziej oczywista, obecna w bezpośrednim doświadczeniu, najbardziej realna, przemożnie narzucająca się naszej percepcji forma bytu" (Sztompka, 2008, s. 25). 
to należałoby uznać problemy (na) styku normatywność/codzienność za zagadnienia ważne dla refleksji pedagogicznej. Szczególnie interesująca wydaje mi się relacja codzienność/normatywność widziana z perspektywy etycznej², dla której podstawowe pytania dotyczą nie tyle tego, „czego pragniemy” czy "chcemy” (albo deklarujemy, że pragniemy), ile tego, „czego powinniśmy pragnąc'”, tego, ze względu na co powinno się podejmować oddziaływania edukacyjne. W tym kontekście uznawane wartości pozwalają oceniać określone cele wychowania, pewne formy oddziaływań edukacyjnych czy pewne formy bycia nauczycielem jako lepsze od innych.

Celem prezentowanego tekstu jest identyfikacja wybranych kontrowersji istniejących wokół normatywnego (etycznego) statusu pedagogicznej codzienności, dzięki czemu, jak sądzę, będę w stanie pokazać, że myślenie i działanie pedagogiczne skazane jest na kontrowersję etyczną, która wykracza daleko poza aksjologiczne uzasadnienia przyjętych celów kształcenia czy wychowania.

W ramach swojego tekstu rozważam pedagogiczne konsekwencje tezy, że skazani jesteśmy na niekonkluzywny spór o moralny status codzienności, przez co rozumiem efekt sygnalizowanych przez Alasdaira MacIntyre’a trudności w przekładaniu języków różnych, antagonistycznych wersji dociekań moralnych, na przekór jemu nie będę jednak argumentował za przyjęciem tradycji arystotelesowsko-tomistycznej jako tej, która najlepiej radzi sobie z ową nieprzekładalnością (MacIntyre, 2009)3.

Rozwijając przyjętą tezę, chcę zwrócić uwagę na trzy możliwości widzenia relacji normatywność-pedagogiczna codzienność. Pierwszy sposób wiąże się ściśle $\mathrm{z}$ obowiązywaniem zasad moralnych $\mathrm{w}$ codziennych doświadczeniach poszczególnych osób, z urzeczywistnianiem przez ludzi w ich codziennym życiu wartości, takich jak dobroć, sprawiedliwość czy prawdomówność. Drugi sposób wiąże się z pytaniem o granice moralności, a więc dotyczy tego, co uznajemy za podlegające ocenie moralnej, a czemu takiego statusu odmawiamy. Trzeci z kolei, koncentruje się wokół pytania o możliwość budowania moralności na codziennych doświadczeniach konkretnych osób.

$\mathrm{Na}$ rzecz przyjętej tezy postaram się zidentyfikować przyczynki do pedagogicznego sporu w każdym z wymienionych obszarów. Kolejność ich omawiania ustaliłem, przyjmując kryterium przewidywanego przeze mnie stopnia kontrowersji i niemożliwości porozumienia co do statusu codzienności, w porządku od najniższego do najwyższego.

2 W ramach tekstu nie podejmuję zatem problemu normatywności widzianego z $\mathrm{np}$. perspektywy prawa czy nauk medycznych.

3 W kwestii niekonkluzywności sporów moralnych w odniesieniu do pedagogicznego myślenia o wspólnocie i roli edukacji zob. Chutorański, Moroz (2013). 


\section{Codzienność jako egzamin z moralności, bariera i szansa na rozwój moralny}

Ludzkie życie bogate jest w doświadczenia pokus, trudnych wyborów, czynności i praktyk, które podlegają ocenie moralnej. Można powiedzieć, że moralność ma znaczenie o tyle, o ile w swoim codziennym życiu człowiek ma możliwość wyboru alternatywnych sposobów zachowania. W takim kontekście o codzienności daje się bez większych kontrowersji myśleć jako o wymiarze ludzkiej egzystencji, w którym ludzie realizują jakąś koncepcję moralności, urzeczywistniają wartości, które uznają za tego warte, wykonują praktyki, które uznają za kluczowe dla jakoś przez nich rozumianego „dobrego” życia. Z perspektywy podmiotowej codzienność daje się rozumieć jako miejsce egzaminu z obowiązywania przyjętych i deklarowanych zasad etycznych, kodeksów moralnych czy wartości.

Podobnie niekontrowersyjnie o codzienności powiedzieć można, eksponując wątki pedagogiczne, że obok, albo raczej dla tego, że jest testem dla nas i naszych moralności, bywa również przeszkodą, utrwalającą automatyzmy i blokującą refleksyjne działanie. Wskazując pedagogiczną wagę tak rozumianej codzienności, warto odwołać się do Lecha Witkowskiego, który pisze:

Musimy odkryć, jakie warunki powinna spełniać nasza postawa, nasz sposób zanurzenia w codzienności, aby jej źródłowość mogła sytuacyjnie w naszej biografii dojść do głosu, byśmy umieli ją odnaleźć, czy wręcz dla nas ją ustanowić. Zwłaszcza że codzienność w jej najbardziej banalnie kojarzonych przejawach pozbawiona jest wglądu, pozbawiona jest refleksji i samowiedzy świadomej własnych ograniczeń. Jest dotknięta swoistym zdwojonym brakiem: brakiem poczucia braku (Witkowski, 2007, s. 279).

$\mathrm{Na}$ tym poziomie refleksji identyfikuję jako ważne dla pedagogicznej refleksji następujące pytania o codzienność: Jak ją zmieniać, by powodowała rozwój moralny dzieci i młodzieży, by okazywała się wykorzystaną szansą na rozwój wrażliwości wychowanków? Jak projektować codzienność wychowawczą, by była wyrazem poszanowania ich praw i podmiotowości? Jaką postawą moralną powinien charakteryzować się wychowawca? Jak szkoła powinna reagować na zdarzenia niecodzienne? (na przykład: Jak powinno się obchodzić święta, by były egzystencjalnie ważne dla uczniów i nauczycieli?).

Między innymi te pedagogiczne pytania oparte na diagnozach i teoriach socjologicznych, psychologicznych czy antropologicznych spotykają się z wymaganiami etycznego urządzenia świata codziennych doświadczeń uczniów. Problem palący jest o tyle, że otwieranie nowych pokoleń na etyczny sposób bycia w świecie musi brać po uwagę, że 
(...) ów świat człowieka (lokalne otoczenie) wcale na tym poziomie nie funkcjonuje w praktyce. W szczególności wielu dorosłych (dojrzałych) jego przedstawicieli i uznanych (wiodących) instytucji nie tylko nie respektuje tego poziomu we własnym działaniu, ale go nawet nie preferuje, odwołując się do innej logiki - innych motywacji i uzasadnień niż te, które za etyczne mogłyby uchodzić (Witkowski, 2000 s. 117).

Wskazać można napięcia w pedagogicznym ujęciu tak rozumianej codzienności, między innymi spytać można: Do których elementów codzienności stosunek powinien być urefleksyjniany, a które ludzkie działania powinny pozostawać nawykowe, za to pewne i szybkie? Rozwijając tę kwestię, warto powiedzieć, że jakkolwiek postawa etyczna wymaga rozwinięcia pewnego poziomu refleksji, to wymaga również wypracowania pewnego zbioru automatyzmów, będących choćby konsekwencją refleksyjnie wypracowanych przez nas standardów etycznego współżycia. Na przykład, jeśli uznajesz, że dbanie o otoczenie jest godne pochwały moralnej, a śmiecenie jest niewłaściwe, to realizacja tego aspektu twojej postawy moralnej nie wymaga zastanawiania się nad zasadnością wyrzucenia papierka do kosza, a nie na ziemię, ilekroć zjesz ulubionego cukierka. Podobnie powinieneś raczej ostrzec ofiarę przed napastnikiem zachodzącym ją od tyłu z długim nożem, aniżeli zastanawiać się nad racjami przemawiającymi za i przeciw takiemu działaniu. Paradoksalnie, w takiej sytuacji zbytnia refleksyjność może być przeszkodą dla realizacji przyjętej formy etyczności. Konkludując, można powiedzieć, że etyczność, a więc wrażliwość na to, co być powinno, wymaga od nas i refleksyjności, i pewnego zbioru automatyzmów. Automatyzmy są częścią naszego życia psychicznego ${ }^{4}$, muszą być również częścią uczestniczenia człowieka w sferze etycznej. Inną sprawą, bardziej kontrowersyjną jest to, co powinno zostać urefleksyjniane, a co podlegać nawykom.

Projektując działania wspomagające rozwój, można postawić pytanie, które z możliwości niemoralnego zachowania powinny być usuwane, a które w trosce o możliwość zaistnienia uczniowskich/nauczycielskich/rodzicielskich wyborów (moralnych) pozostawione. Problemy może również powodować wskazanie jednoznacznych kryteriów rozpoznawania barier i możliwości rozwoju moralnego.

4 Jak pisze J. Haidt: „[S]ądy moralne przypominają sądy estetyczne. Kiedy widzisz jakiś obraz, na ogół od razu, automatycznie wiesz, czy on Ci się podoba. Kiedy ktoś prosi Cię o uzasadnienie tej opinii, zaczynasz konfabulować. Tak naprawdę nie wiesz, dlaczego dany przedmiot wydaje Ci się piękny, ale - jak wykazał Gazzaniga w swoich badaniach prowadzonych wśród pacjentów z rozszczepionym mózgiem - Twój moduł interpretujący (jeździec) jest mistrzem w wymyślaniu wiarygodnych powodów. Szukasz przekonującego uzasadnienia swojej pochlebnej opinii o ocenionym obrazie (...)” (Haid, 2007, s. 49). Zob. Gazzaniga, 2011; Kahneman, 2012; Haidt, 2014. 
Jest tak, jak sadzę, z co najmniej kilku powodów, część z nich wiąże się z koniecznością postawienia pytań o granice moralności.

\section{Granice moralności a pedagogiczna codzienność: grzech, porażka czy coś innego?}

Spór o codzienność dotyczyć może definiowania tego, które z codziennych praktyk ludzkich wpisują się w porządek wartościowania moralnego, a które takiemu wartościowaniu nie podlegają. Jak zauważa z perspektywy socjologii moralności Maria Ossowska:

(...) do zakresu pojęcia moralności należą przedmioty podlegające uznaniu albo naganie i (...) różnice w ich ocenie wpływają na zmianę zakresu pojęcia [moralności - przyp. M.Ch.]. Kto uważa jakieś postępowanie za obojętne, będzie skłonny sprawę z zakresu moralności wyłączyć (Ossowska, 2005, s. 178).

Podać można tu kilka przykładów, jak noszenie odpowiedniego stroju, które dla jednych może się wiązać z wyborem estetycznym, dla innych oznaczać może przejaw (nie)etyczności (na przykład bardzo mocny makijaż uczennicy/ ucznia może być przedmiotem takiej kontrowersji w klasie szkolnej); sposób odżywiania (może być uznany za kwestię wyszukanego smaku, może również być palącym problemem etycznym); możliwość sprzedaży nazwy szkoły dyskontowi spożywczemu, może być poddawana wartościowaniu etycznemu, może również zostać uznana za podlegającą wartościowaniu ekonomicznemu.

W tym miejscu warto odwołać się do Marii Ossowskiej, która pisze, że samo „wyznaczenie granic moralności jest już sprawą moralną” (Ossowska, 2005, s. 178). W samej etyce jednak brak zgody dotyczącej przyznania pierwszeństwa jakiejś wizji moralności łączy się z brakiem zgody co do jej granic. W zależności od przyjętej teorii różny może być zakres obowiązywania sfery podlegającej ocenie moralnej. W teoriach deontologicznych (i odwołujących się do nich koncepcjach psychologicznych) mamy do czynienia z węższym rozumieniem sfery moralnego funkcjonowania człowieka (na korzyść sfery pozamoralnej) aniżeli w wywodzącej się od Arystotelesa teorii cnoty, której zwolennicy skłonni są umieszczać w centrum swoich dociekań (nie pytanie: „Co jest słuszne?”, ale) pytanie: „Kim powinienem być?”.

Ilustrując punkty sporu dotyczące określania granic moralności, można postawić następujące pytanie: Które czyny wychowawcy wpisują się w porządek moralny, a które traktować jako wyraz jego troski o skuteczność? Zapytajmy na przykład, jaki rodzaj motywacji jest dopuszczalny w procesie wychowywania? Czy nauczyciel może okłamywać ucznia, jeśli przewiduje, że dzięki 
temu wywoła w nim motywację do wysiłku poznawczego i twórczej pracy? Czy jeśli to przyniesie korzyści w postaci zwiększenia czytelnictwa uczniów, dopuszczalne jest, aby stosował finansowe zachęty?

Odwołując się do badań Bogdana Wojcieszke dotyczących psychologicznego rozumienia zjawisk społecznych, można zapytać, które z pedagogicznych niepowodzeń uznawać należy za grzech, a które za porażkę? (Wojcieszke, 1999). Właściwym wymiarem oceny których czynów pedagoga jest skuteczność, a których obowiązek moralny?

Warto w tym miejscu zwrócić uwagę na, sygnalizowany między innymi przez Tomasza Szkudlarka (2001), proces zagospodarowywania przestrzeni etycznej refleksji nad edukacją przez logikę neoliberalizmu i przesunięcie debaty o edukacji w stronę traktowania jej jako narzędzia do realizacji celów ekonomicznych (redukcja kształcenia do przygotowania „kapitału ludzkiego”) czy wdrażania postaw konsumenckich (zob. Potulicka, Rutkowiak, 2010). Ten ruch zdaje się świadczyć o kurczeniu się sfery tego, co w codzienności uznajemy za podlegające wartościowaniu moralnemu, na korzyść sfery, której logikę wyznacza troska o skuteczność, ekonomiczny zysk. Jak pisze Michael Sandel, „Rynek nie grozi palcem. Nie robi różnicy między preferencjami szlachetnymi i niskimi. Każda ze stron transakcji sama decyduje, jaką wartość przypisuje temu, co podlega wymianie" (Sandel, 2012, s. 27). Natomiast warto pamiętać, o tym że, jak pisze ten autor:

(...) kiedy dobre rzeczy w życiu przemieniamy w towar, to ulegają wypaczeniu, degeneracji. Dlatego właśnie decydując, jakie dobra mają podlegać prawom rynku, a od których rynek powinien się trzymać z daleka, musimy zdecydować, jak określać wartości takich dóbr, jak: zdrowie, edukacja, życie rodzinne, przyroda, sztuka, obowiązki obywatelskie itd. To są pytania natury moralnej i politycznej, a nie czysto ekonomicznej (Sandel, 2012, s. 23).

Postawmy kilka pytań o granice tego, co powinno podlegać wartościowaniu moralnemu, a co nie, wprost odwołujących się do rzeczywistości edukacyjnej: Czy można, jeśli poprawi to finanse szkoły, zaproponować zatroskanym o dobro swych dzieci rodzicom, za odpowiednią dopłatą, możliwość uczęszczania ich dzieci do klas o „podwyższonym standardzie” z mniejszą liczbą uczniów, „lepszymi” nauczycielami (na przykład takimi, którzy mają wyższe wykształcenie, dodatkowe kwalifikacje etc.), lepszymi pomocami naukowymi, wygodniejszymi meblami, podczas, gdy inne dzieci z tej samej szkoły, których rodziców nie stać na dodatkowy abonament, mają gorsze, „normalne” warunki (które jednak, dzięki wprowadzeniu abonamentów, uległy poprawie)? Czy można rodzicom zaproponować wykupienie możliwości dodatkowej konsultacji z nauczycielem sytuacji edukacyjnej ich dziecka? Zapytajmy: „czy są rzeczy, które można kupić za pieniądze, ale nie powinno się tego robić?" (Sandel, 2012, s. 117). 


\section{Poziom sporu o źródła moralności}

Ostatnia z przygotowanych przeze mnie propozycji widzenia relacji pedagogiczna codzienność-normatywność wiąże się z kontrowersją dotyczącą źródłowości moralności.

Codzienność może być różnie przeżywana. O ile przeżycia konkretnych ludzi w konkretnych warunkach egzystencjalnych składają się na ich subiektywne pojmowanie dobra, tworzenie indywidualnych, potocznych teorii etycznych, o tyle warto postawić pytanie, czy mogą one być uzasadnioną podstawą dla jakiejś formy etyki? Czy, przeciwnie, codzienność może być tylko miejscem testu i obowiązywania ustanowionych i uzasadnianych jakimś autorytetem metafizycznym i/lub procedurą rozumowania niepoddającą się zmianie pod wpływem codzienności?

To, moim zdaniem, największe pole kontrowersji, dotyczące styku codzienność/etyczność. W istocie odpowiedź na to pytanie wydaje się do pewnego stopnia zbiegać z pytaniem o możliwość ustanowienia uniwersalnego i możliwego do przyjęcia przez wszystkich projektu moralnego. Tu kontrowersja pedagogiczna może dotyczyć wyboru i uzasadnienia wartości stanowiących podstawę celów kształcenia i wychowania. W jakim stopniu są one uzależnione od kontekstów społecznych i kulturowych, opinii poszczególnych rodziców i wychowawców (kształtowanych między innymi pod wpływem wyzwań codzienności), a na ile są uniwersalne i niezmienne?

Sądzę, że możliwość ustanowienia jakiegoś projektu moralnego na codziennych doświadczeniach konkretnych osób i grup jest szczególnie istotna z punktu widzenia badaczy dopuszczających różne, równoprawne sposoby opisu rzeczywistości. Jak zauważa Adam Grobler, gdyby „racja leżała po stronie relatywizmu poznawczego $\mathrm{z}$ tego właśnie powodu, że wszystkie teorie są normatywnie obciążone, to i obiektywne porównania systemów normatywnych byłyby wykluczone (...) relatywizm poznawczy pociąga za sobą relatywizm moralny" (Grobler, 2002, s. 147). Pozostaje bowiem pytanie, w czym moja perspektywa moralna jest lepsza od każdej innej, skoro mój ogląd świata jest tylko jednym $\mathrm{z}$ wielu możliwych? Jeśli dodamy do tego zasygnalizowane przeze mnie za Marią Ossowską problemy w wytyczaniu granic moralności, to sprawa staje się tu niezwykle skomplikowana (ponieważ to, co dla jednego podlega wartościowaniu moralnemu, dla innego będzie kwestią na przykład skuteczności).

Nawet jeśli dopuszczamy, że istnieją pewne uniwersalne i wspólne wszystkim (zdolnym do współtworzenia projektu moralnego) elementy doświadczania codzienności (na przykład cierpienie), na których można by oprzeć budowę jakiegoś projektu moralnego, pozostaje artykułowany przez Davida 
Hume’a (2005, s. 546-547) problem braku możliwości wydedukowania tego, co powinno być (wartości) z tego, co jest (faktów). W wyprowadzanych wnioskach nie może być niczego, czego nie byłoby w przesłankach, dlatego wniosków o charakterze moralnym (powinnościowym) nie można wyciągać z przesłanek (sądów) opisowych. I tak na przykład: przejście od przesłanki (załóżmy na potrzeby mojego wywodu, że empirycznie potwierdzonej): „wszyscy ludzie uznają tolerancję za najwyższą wartość”, do konkluzji; „powinienem być tolerancyjny”, jest możliwe tylko dzięki dodatkowej przesłance: „powinienem czynić to, co za najwyższą wartość uznają wszyscy ludzie”. Dlaczego jednak tę, a nie inną dodatkową przesłankę należy przyjmować? Tej kwestii empirycznie ustalić nie sposób.

Rozwijając to zagadnienie, powiedzmy, że nawet jeśli uznamy za pewne (potwierdzone empirycznie), że ludzie mają takie, a nie inne preferencje dotyczące wartości i że w zdecydowanej większości mają określone i wspólne poglądy na temat tego, czym jest dobro moralne, a czym zło, zawsze istnieje prawdopodobieństwo, że wszyscy oni się mylą, a to, co uznają za godne pochwały, jest niegodziwe. W tym kontekście postawić można pytanie: „Czy edukacja, której chcemy dla naszych dzieci (ma wystarczające podstawy), jest edukacją, którą powinniśmy dostać?".

\section{Pedagogiczne uwikłania w niekonkluzywne spory moralne}

Rozpatrywana przeze mnie niekonkluzywność na poziomie teoretycznym związana jest przede wszystkim z niewspółmiernością argumentów moralnych wykorzystywanych w sporze przez jego uczestników, odwołujących się do różnych tradycji dociekań moralnych. Jak pisze MacIntyre:

(...) przestrzeganie praw logiki jest jedynie koniecznym, ale niewystarczającym warunkiem racjonalności teoretycznej czy praktycznej. Spór dotyczący fundamentalnej natury racjonalności powstaje bowiem na gruncie tego, co należy dodać do przestrzegania praw logiki, aby uzasadnić przypisane cechy racjonalności - sobie samemu, innym osobom, sposobom dociekań, uzasadnieniom przekonań, obieranym sposobom działania lub też ich uzasadnieniom; następnie kontrowersja ta rozciąga się na kwestie tego, na czym polega racjonalność postępowania w obliczu tego sporu (MacIntyre, 2007, s. 51).

Ponieważ w ramach danej tradycji wartości funkcjonują w określonym kontekście innych wartości, sposobach uznawania określonych praktyk za racjonalne. Mówiąc kolokwialnie, uznawane wartości są „w pakiecie”, z którego zrezygnować bez uszczerbku dla nich nie sposób. Jak pisze Michael Walzer 
Często (...) to, co dla jednej grupy jest wartością fundamentalną (na przykład zbawienie albo poznanie Boga), dla innej może niewiele znaczyć - do tego stopnia, że ta pierwsza grupa $\mathrm{z}$ trudem jest $\mathrm{w}$ stanie zrozumieć, w jaki sposób członkowie tej drugiej mogą być ludźmi moralnymi (Walzer, 2012, s. 30).

Rozwijając ten wątek, zaproponuję - jak sądzę - możliwe do logicznego utrzymania następujące, sprzeczne z sobą (zarówno na płaszczyźnie teorii, jak i konsekwencji dla praktyki edukacyjnej) rozumowania, odwołujące się do metafor "tabula rasa” i „metafory organicznego wzrostu” (Kohlberg, Mayer, 2000). Pierwsze z nich: Dziecko, które przyszło właśnie na świat pomimo wrodzonych zdolności nic nie wie o historii swoich przodków, o muzyce klasycznej, nie zna wierszy Wisławy Szymborskiej, nie ma zdania na temat Pana Tadeusza, nie potrafi opowiedzieć się po którejś ze stron w sporze konserwatystów z liberałami, nie potrafi tworzyć stron www... etc. W tym sensie jest ono niezapisaną (treściami kultury) tablicą. Tylko poprzez edukację umożliwiającą nabywanie cenionych społecznie umiejętności, poznawanie zwyczajów, historii, kultury, zdobyczy nauki dziecko staje się w pełni rozwiniętym (w pełni wartościowym) człowiekiem.

Drugie: Dziecko, które przyszło na świat, ma naturalną zdolność do nawiązywania kontaktu z innymi, ma naturalną skłonność do zadawania pytań. Jego natura każe mu nieustannie eksperymentować, poszukiwać nowych rozwiązań. Tę ciekawość należy zachować, wychowawca powinien wspierać zainteresowania dziecka, powinien zapewnić mu komfort psychiczny, wykazać zrozumienie dla jego nieudanych poszukiwań i nie narzucać mu bezwzględnie tempa rozwoju i treści, które sam lub grupa, do której należy, uznaje za ważne. Tylko dzięki temu dziecko może rozwinąć w sobie to, co pozwoli mu się stać szczęśliwym, samorealizującym się (w pełni wartościowym) człowiekiem.

Jak sądzę, każde $\mathrm{z}$ tego typu uzasadnień daje się logicznie uspójnić, cały problem polega jednak na tym, od czego w naszym rozumowaniu należy wyjść i jaki sposób argumentacji należy uznać za racjonalny. To z kolei wiąże się już z projektami moralnymi konkretnych osób i grup, realizowanymi przez nie koncepcjami dobra i uznawanymi „pakietami” wartości.

Dlatego też - jak argumentuje MacIntyre - debata tocząca się między stanowiskami różniącymi się w kwestiach fundamentalnych jest faktem, wszelako z konieczności jest ona niekonkluzywna. Zwolennikom każdego z wojujących stanowisk zazwyczaj wydaje się, że nie da się go obalić. I rzeczywiście, w świetle jego własnych kryteriów i standardów argumentacyjnych w praktyce obalić go się nie da. Z kolei swoim oponentom każde z walczących stanowisk $\mathrm{w}$ analogiczny sposób wydaje się niedostatecznie uzasadnione przez racjonalne argumenty (MacIntyre, 2009, s. 28).

Pedagogiczne uwikłania w moralność można zilustrować, odwołując się do koncepcji psychologicznych przyjmowanych w rozumieniu/projektowaniu 
oddziaływań edukacyjnych. Koncepcje rozwoju, w tym koncepcje psychologiczne, pełne są rozstrzygnięć wartościujących o charakterze normatywnym/ etycznym, o których powiedzieliśmy przed chwilą, że nie mogą wynikać bezpośrednio z danych empirycznych. Aby opisać psychologicznie coś takiego jak rozwój moralny, potrzebujemy jakiejś wyjściowej teorii moralności (na przykład etyka kantowska jako pokonwencjonalny stopień rozumowania moralnego w teorii L. Kohlberga). O ile odrzucenie danej psychologicznej koncepcji rozwoju nie musi wiązać się $\mathrm{z}$ odrzuceniem leżącej u jej podstaw koncepcji moralności, a wynika na przykład z braku empirycznego jej potwierdzenia (mogę odrzucić teorię Kohlberga, jednocześnie pozostając kantystą), o tyle odrzucenie koncepcji moralnej, moim zdaniem, musi się wiązać $\mathrm{z}$ odrzuceniem budowanej na niej koncepcji rozwoju moralnego (na przykład opowiadając się po stronie zwolenników etyki cnoty, powinienem z dużą rezerwą odnosić się do teorii rozumowania moralnego Kohlberga, nawet gdyby przechodziła pozytywnie wszelkie testy empiryczne) (Chutorański, 2012). Warto w tym kontekście odwołać się do Janusza A. Majcherka, który pisze:

(...) dla opisu zachowań podejmowanych w zakresie etyki (etycznych) trzeba uprzednio wiedzieć (ustalić), co w ten zakres wchodzi, a więc przyjąć kryteria wyodrębniania, mające charakter normatywny. Aby przystąpić do badania i relacjonowania, w jaki sposób ludzie faktycznie wypełniają powinności etyczne, należy wcześniej wiedzieć, na czym owe powinności polegają (co jest kryterium je wyodrębniającym) (Majcherek, 2011, s. 158).

Dlatego moralnie kontrowersyjne może być wykorzystanie tej, a nie innej teorii dotyczącej psychologicznego rozwoju moralnego.

\section{Konkluzja}

Każda próba uzasadnienia działań pedagogicznych jest z konieczności uzasadnianiem o charakterze etycznym i odwołuje się przede wszystkim do tego, co „powinno być”, to z kolei nigdy nie jest logiczną konsekwencją danych empirycznych, faktów (nawet uzależniając cele edukacji od wymagań rynku, przyjmujemy wprost lub implicite dodatkową przesłankę, że to "rynek” powinien być etyczną instancją tego, czego należy nauczać/uczyć się i ku czemu należy wychowywać etc.). Wybory dotyczące wartości są wpisane w te aspekty działalności edukacyjnej, które wiążą się choćby z możliwymi sposobami rozumienia rzeczywistości edukacyjnej w jej najbardziej codziennych przejawach.

Powyżej starałem się wskazać niektóre „newralgiczne”, ale stale obecne w myśleniu pedagogicznym miejsca potencjalnie otwarte na kontrowersje dotyczące wartości. Swoim artykułem opowiadam się przeciwko tezie, że wy- 
soki poziom racjonalności pozwoli na wypracowanie neutralnych zasad prowadzenia moralnego sporu, a w konsekwencji doprowadzi nas w końcu do rozwiązania moralnych kontrowersji dotyczących codzienności. Zgadzając się między innymi z niektórymi argumentami komunitarian, nie sądzę, żeby proponowane $\mathrm{w}$ ramach podejścia liberalnego uznanie prymatu słuszności nad dobrem - w stylu rawlsowskiej zasłony niewiedzy (Rawls, 2009) - mogły rozwiązywać problem teoretycznej niekonkluzywności (MacIntyre, 2007, 2009; Sandel, 2009; Walzer, 2012). Postulując uruchomienie procedury i zasad debaty jako sposobu dochodzenia do wspólnego „projektu moralnego”, zakładamy już moralność „którą można uzgodnić w ramach debaty” prowadzonej na określonych (sprawiedliwych) zasadach, które powinny być podzielane przez wszystkich uczestników. Cały problem polega na tym, że przyjęcie już takich zasad może naruszać lub wykluczać określone stanowiska moralne. „Proceduralizm jest pociągający, ponieważ pozornie (...) pozwala na rozbieżne rezultaty"(Walzer, 2012, s. 27). Okazuje się jednak, że spełniając liberalne warunki uczestnictwa w sporze o wartości, musimy jednocześnie rezygnować $\mathrm{z}$ wielu naszych przekonań. W konsekwencji „rozmówcom pozostaje niewiele istotnych kwestii, o które mogą się spierać i o których decydować" (Walzer, 2012, s. 24-25).

Sądzę jednak, że choć teoretyczna konkluzywność w sporze o wartości wydaje się nieosiągalna, to jej brak nie zwalnia nas z odpowiedzialności za troskę o etyczną wartość codziennych doświadczeń podmiotów edukacji. Sygnalizowana $\mathrm{w}$ ramach prezentowanego tekstu $\mathrm{w}$ odniesieniu do pedagogicznej codzienności refleksja nad niewspółmiernością argumentów poszczególnych tradycji moralnych może się okazać niezwykle przydatna w wysiłku poznawczym motywowanym tak rozumianą troską, ponieważ pozwala z jednej strony lepiej zidentyfikować istotę toczonego sporu, $\mathrm{z}$ drugiej umożliwić taką dyskusję, która uruchomiłaby testowanie określonych stanowisk w ramach uznawanych przez nie standardów racjonalności. Wysiłek jest wart podjęcia, szczególnie w kontekście następujących słów Petera Wincha: „podczas gdy problemy naukowe zajmują człowieka dopiero wtedy, gdy zdecyduje się poświęcić nauce, problemy moralne nie zaczynają go dotyczyć wtedy, gdy zdecyduje zająć się moralnością" (Winch, 1990, s. 46-47). „Co więcej, człowiek, który nie stawia czoła problemom moralnym, podlega osądowi moralnemu” (Winch, 1990, s. 47).

\section{Bibliografia}

Chutorański M. (2012). Moralność, rozwój moralny, wychowanie moralne. „Teraźniejszość-Człowiek-Edukacja”, nr 2 (58), s. 97-106. 
Chutorański M., Moroz J. (2013). Whose community? What education?. „International Forum for Education", nr 1 (5), s. 26-38.

Gazzaniga M.S. (2011). Istota człowieczeństwa. Co sprawia że jesteśmy wyjątkowi, tłum. A. Nowak. Smak Słowa, Sopot.

Grobler A. (2002). Prawda a względność. Wydawnictwo Aureus, Kraków.

Haid J. (2007). Szczęście. Od mądrości starożytnych po koncepcje współczesne, tłum.

A. Nowak. Gdańskie Wydawnictwo Psychologiczne, Gdańsk.

Haidt J. (2014). Prawy umyst. Dlaczego dobrych ludzi dzieli religia i polityka, tłum. A. Nowak-Młynikowa. Smak Słowa, Sopot.

Hume D. (2005). Traktat o naturze ludzkiej, tłum. Cz. Znamierowski. Fundacja Aletheia, Warszawa.

Kahneman D. (2012). Puapki myślenia. O myśleniu Szybkim i Wolniejszym, tłum. P. Szymczak. Media Rodzina, Poznań.

Kohlberg L., Mayer R. (2000). Rozwój jako cel wychowania, w: Z. Kwieciński (red.), Alternatywy myślenia o/dla edukacji. IBE, Warszawa, s. 21-65.

MacIntyre A. (2007). Czyja sprawiedliwość? Jaka racjonalność?, tłum. A. Chmielewski i inni. Wydawnictwa Akademickie i Profesjonalne, Warszawa.

MacIntyre A. (2009). Trzy antagonistyczne wersje dociekań moralnych. Etyka, Genealogia i Tradycja, tłum. M. Filipczuk. Wydawnictwa Akademickie i Profesjonalne, Warszawa.

Majcherek J.A. (2011). Etyka powinności. Defin, Warszawa.

Ossowska M. (2005). Socjologia moralności zarys zagadnień. Wydawnictwo Naukowe PWN, Warszawa.

Potulicka E., Rutkowiak J. (2010). Neoliberalne uwikłania edukacji. Oficyna Wydawnicza Impuls, Kraków.

Rawls J. (2009). Teoria sprawiedliwości, tłum. M. Panufnik. Wydawnictwo Naukowe PWN, Warszawa.

Sandel M.J. (2012). Czego nie można kupić za pieniądze. Moralne granice rynku, tłum. A. Chromik, T. Sikora. Kurhaus, Warszawa.

Sandel M.J. (2009). Liberalizm a granice sprawiedliwości, tłum. A. Grobler. Wydawnictwa Akademickie i Profesjonalne, Warszawa.

Szkudlarek T. (2001). Ekonomia i moralność: przemieszczenia dyskursu edukacyjnego. „Teraźniejszość-Człowiek-Edukacja”, numer specjalny, s. 165-191.

Sztompka P. (2008). Życie codzienne - temat najnowszej socjologii, w: Socjologia codzienności, P. Sztompka, M. Bogunia-Borowska (red.). Wydawnictwo Znak, Kraków.

Walzer M. (2012). Moralne maksimum, moralne minimum, tłum. J. Erbel. Wydawnictwo Krytyki Politycznej, Warszawa.

Witkowski L. (2007). Codzienność i jej pedagogiczne przekleństwa, w: L. Witkowski, Między pedagogika, filozofia i kulturą. Studia, eseje, szkice, t. III. IBE, Warszawa.

Winch P. (1990). Etyka a działanie, tłum. D. Lachowska, T. Szawiel. Państwowy Instytut Wydawniczy, Warszawa.

Witkowski L. (2000). Przekroje analityczne kwestii edukacyjnej, w: Z. Kwieciński (red.), Alternatywy myślenia o/dla edukacji. IBE, Warszawa, s. 113-132. 
Wojcieszke B. (1999). Grzech czy porażka. Moralne i sprawnościowe kategorie w potocznym rozumieniu świata społecznego, w: B. Wojcieszke, M. Jarymowicz (red.), Psychologia rozumienia zjawisk społecznych. Wydawnictwo Naukowe PWN, Warszawa-Łódź. 